\title{
Factors Influencing Adoption of Soil and Water Conservation Measures in India: Reviewing the Evidence
}

\author{
Dinesh Chand Meena ${ }^{1 *}$, C.A. Rama Rao ${ }^{2}$, B.L. Dhyani ${ }^{3}$, Pradeep Dogra ${ }^{3}$, \\ S.K. Dubey ${ }^{1}$ and P.K. Mishra ${ }^{3}$
}

${ }^{1}$ Indian Institute of Soil and Water Conservation, Research Centre, Agra (India)-282006

${ }^{2}$ Central Research Institute for Dryland Agriculture, Hyderabad (India) -500 059

${ }^{3}$ Indian Institute of Soil and Water Conservation, Dehradun (India) -248195, India

*Corresponding author

\section{A B S T R A C T}

\section{Keywords}

SWC measures, Land degradation,

Ecosystem,

Determinants of adoption technologies, Socioeconomic factors

\section{Article Info}

Accepted:

15 May 2020

Available Online:

10 June 2020
In India an estimated 121 million hectare (Mha) suffers from various forms of land degradation and it has been identified as one of the most serious problems that threaten the sustainability of agriculture. Over the past decades successive development projects have promoted a variety of soil and water conservation (SWC) measures to addressing the problems of low agricultural productivity and soil degradation. However, these measures have seldom been adopted on a large scale. Social scientists have been seeking to understand the reasons for their adoption and non-adoption. This paper reviews the past studies in order to identify those socio-economic, institutional and technical factors that explain adoption or lack of it for understanding the success or failure of these SWC measures. The results showed that educational level of the household head, awareness, age, land holding size, perceptions about soil erosion, access to credit; land tenure, offfarm employment and income, information sources and extension contact significantly affect farmers' adoption decision and the extent of soil and water conservation measures. Therefore, to encourage adoption of improved conservation measures, the extension, institutional support programs and projects that promote soil and water conservation measures should have strategies which focus on enhancing the awareness and willingness of farmers along with increasing income of the farmers.

\section{Introduction}

Agriculture has been and will continue to be the lifeline of the Indian economy, which contributed17.2 percent of country's GVA in 2017-18 (Anonymous, 2018). Out of an estimated 194.40 Mha Gross cropped area, $101.82 \mathrm{Mha}$ (52 per cent) is rainfed (Anonymous, 2016). Even after realization of full irrigation potential of the country, 50 per cent of net sown area will continue as rainfed (Venkateswarlu and Prasad, 2012). Agriculture suffers from a number of biophysical and socio-economic constraints, which affect productivity of crops and livestock. These include high, low and erratic rainfall, soil loss by run-off, high evaporation, land degradation and poor productivity. 
Efficient conservation of soil and water is the vital issue in sustainable and profitable farming.

In India, ever rising population, declining per capita land and water availability, soil erosion and land degradation are posing serious threat to food, economic and ecological security. Land degradation consists of the deterioration of soil quality and thus of its productive capabilityand it has been widely recognized as a serious problem (Reddy et al., 2004; Singh et al., 2009). As per latest harmonized database about $121 \mathrm{Mha}$ are come under land degradation (Anonymous, 2010). "How to feed the world" is an increasingly urgent and looming concern enunciated by local community groups to national and international governing bodies. The country's population is expected to reach 1660 million by the year 2050 and for which 349 million tons of food grains will be required. It is also projected that land area available in 2050 would be 137 million hectares (Gamit et al., 2015).

Depletion of soil and water resources is a major constraint to agricultural production and food security in India. Among various states of India, Jammu \& Kashmir and Nagaland have maximum share of their land (94 per cent) under degradation. This is primarily due to large areas under mountains, cold deserts and other such degraded lands. The agriculturally predominant states like Uttar Pradesh, Madhya Pradesh and Karnataka have 63, 50 and 46 per cent share of their total land under land degradation, respectively (Kumar et al., 2011). The extent of land degradation in the country is posing a big threat to the natural resources. Hence, control of land degradation is most crucial for sustainable agricultural production.

For coping with these problems, over the past decades a variety of soil and water conservation (SWC) measures have been implemented in the country in watershed mode. These measures can foster production of various kinds of ecosystem services that have both upstream and downstream benefits. By implementing measures that maintain or restore the capacity of soil to retain water along with nutrients and organic matter, farmers can significantly reduce agricultural water demand, reduce vulnerability to climate extremes of drought and flooding, and also increase soil carbon storage as well as productivity. Therefore, prudent use and management of these basic natural resources and effective conservation practices are the issues of prime importance for sustainable development of the country.

The Indian Institute of Soil and Water Conservation (IISWC), Central Research Institute for Dryland Agriculture (CRIDA) and Central Arid Zone Research Institute (CAZRI) are the major institutes in the Natural Resource Management (NRM) Division of Indian Council of Agricultural Research (ICAR). The common broad mandate of IISWC, CRIDA and CAZRI is to conduct research in the field of natural resource management particularly in soil and water conservation (SWC) relevant to their specific regions.

An understanding of the determinants of a farmer's decision to adopt a particular SWC measures among the available choices is crucial to provide insights and identify target variables that enhance the adoption of SWC measures. SWC programmes can be more cost effective if they are based upon an understanding of farmer's perceptions about soil erosion (Shankar et al., 2007). In this context, understanding adoption patterns of soil and water conservation is crucial in terms of their utility and their further scope of improvement. In this paper, we are seeking to identify bio-physical, socio-economic and 
other factors that appear to influence a farmer's decision to adopt SWC practices. The understanding of these factors would assist in formulation and implementation of policy programme designed to promote voluntary adoption by farmers and to indicate future research directions.

\section{Determinants of adoption of Soil and Water Conservation (SWC) technologies}

The researchers have sought to explain the adoption of SWC measures by farmers. They selected a number of imperative independent variables in their analysis based on prior theory and test, to determine which variables correlated significantly with adoption of SWC measures. This paper analysed the adoption of SWC measures using the different methodology available in wide range of literatures for temporal and spatial variations.

The variations were observed in sample sizes and statistical methods among the analyses. For example, some analyses rely on tabular method to find out the extent of adoption of SWC measures and on non-parametric (chisquare) tests, which reveal mere associations between variables, whereas others studies use regression model, which simply shows the causal relationships between dependent and independent variables.

Several recent studies use Ordinary Least Squares (OLS), while other uses qualitative or dummy dependent variable (Logit/Probit model) by assigning a score of 0 or 1 to express adoption and non-adoption. However, a regression analysis is more plausible than mere correlation, meanwhile, Feder et al., (1985) argued that the Logit/Probit models are superior over Ordinary Least Square (OLS). However, at elementary level, even sample size can also influence outcomes especially with respect to test of significance.
In at least one instance, the variable was found to significantly correlate with adoption of soil and water conservation measures presented in Table 1 and these variables are grouped within four relevant categories.

The differences in quality among the methodologies, as well as those differences that relate to the locus of study and the technology under study, make the aggregation of the analyses challenging. However, the important variables those were found to significantly correlate with adoption of SWC measures are meticulously analysed under following heads.

\section{Farm household characteristics}

The adoption of new technologies varied from farmer to farmer, researchers have started to focus on certain characteristics of farmers in an effort to explain this variation. In the case of adoption of soil conservation technologies, researchers (Stonehouse, 1991; Mahboubi, et $a l ., 2005)$ emphasize awareness on the part of farm operators of soil erosion or other soil problems as a prerequisite to adoption of these technologies. The awareness about the existence and extent of runoff loss, low agriculture productivity, nutrient and water depletion; and its contributory factors are prerequisite condition for farmers to undertake any SWC measures to arrest the problem (Shankar et al., 2007). Lack of knowledge and awareness about SWC measures contribute to non-adoption of these measures (Bagdi et al., 2001). Indeed, framer's perception of effect of soil and water degradation on crop yield is frequently observed to be positively correlated with the adoption of SWC practices (Roger, 2003; Barman and Das, 2010; Benal et al., 2010). Without awareness about effectiveness and profitability of SWC measures via communication channels, adoption is improbable. 
Age is conjectured to have negative impact on adoption of conservation measures as young farmers are ready to take risk and perceive higher benefit from SWC measures (Soule et al., 2000; Mondal et al., 2013). Thus, the variable age was observed to be negatively (Benal et al., 2010; Singh et al., 2011) as well as positively correlated (Badal et al., 2006) to conservation practices. However, some researchers have observed age to be nonsignificant variable (Barman and Das, 2010).

Availability of farm labour had significantly influenced adoption of SWC measures. Thus, the variable family size was found to be positive and significant with conservation measures (Barman and Das, 2010) and land leveling (Singh and Singh, 2004), however, Singh and Singh (2004) and Regassa et al., (2003) have found number of family labour to be a non-significant variable and even negatively correlating with resource conservation technologies adoption (Singh et al., 2011).

The education level of farmer has been assumed to influence adoption decisions of farmers because of the assumed link between education and knowledge. Indeed, education commonly correlates positively with adoption of agriculture conservation practices (Benal et al., 2010; Singh et al., 2011; Mondal et al., 2013); however, some researchers have found education to be an non-significant factor (Regassa et al., 2003; Barman and Das, 2010). Singh and Singh (2004) found that education was significantly associated with bunding whereas in case of leveling, contour bunding, nala bunding and inter cropping, it was not found to be significant.

Social participation and socio-economic status variables had a positive relationship with the adoption of conservation measures such as intercropping and contour cultivation (Singh and Singh, 2004). Similarly, Benal et al., (2010) found that economic motivation, attitude towards modern technology, innovativeness and scientific orientation had significant and positive correlation with adoption of recommended dry land agricultural technologies. SWC measures can become more cost effective if they are based upon an understanding of farmer's perceptions about soil erosion and conditions under which they adopt and maintain soil conservation measures (Kerr and Sanghi, 1992).

\section{Farm biophysical characteristics}

Apart from characteristics of farm households, analysis of adoption of SWC technologies has often paid attention to a variety of biophysical characteristics of the farm itself. Land holding size is very important variable among farm biophysical characteristics. It is hypothesized that owners of larger farm are more willing to adopt a new technology. Land holding is often, but not always, related to innovative adoption as larger areas tend to increase the overall benefits of adoption of SWC practices (Singh et al., 2011 and Mondal et al., 2013).

There is also negative correlation observed in a few cases (Benal et al., 2010) which can be attributed to possible intensive use of a small parcel of more productive land within the farm. Some other studies have shown no significant relationship between farm size and adoption of these measures (Barman and Das, 2010 and Pande et al., 2011).

Hence, the overall impact of farm size on adoption is dependent on many factors through which it influences the adoption decision of SWC measures. Barman and Das (2010) also found that the number of livestock reared, fragmentation of plots and slope of land had a negative influence on the adoption of conservation measures. 


\section{Farm financial characteristics}

There are many farm financial variables which influence the adoption of SWC technologies. With respect to credit worthiness, it is hypothesized that adoption of conservation measures involves sufficient financial well-being. In support of this view, many studies that investigated the impact of income, gross income and farm profitability on adoption revealed positive correlation (Gould et al., 1989and Pande et al., 2011). With respect to off farm income and off farm employment, several researchers found negative relationship with adoption of conservation measures (Badal et al., 2006 and Benal et al., 2010). Farmers with substantial off-farm employment and income tend to invest less in soil conservation than those without (Kerr and Sanghi, 1992).

Regarding land tenure, some studies associating farm tenure (owning or renting) to use of SWC measures showed that ownership is significantly related to use of beneficial measures but not to use of unbeneficial measures. Farmers who cultivate their own land are much more likely to invest in soil conservation than those renting or sharecropping someone else's land (Kerr and Sanghi, 1992). Barman and Das (2010) also have shown positive significant relationship between land tenure and adoption of SWC measures. Farmer with permanent 'land patta' demonstrated more inclination towards adoption of conservation measures as compared to 'periodic patta' holder. Whereas, Pande et al., (2011) found land tenure has not turned out to be a significant variable affecting decision to invest on conservation measures.

Sigh et al., (2011) found that net return of farm was most important and crucial variable influencing adoption of resource conservation technology. The adoption of new conservation technologies and investments depend on relative returns and stability of incomes that new options provide compared to existing alternatives. Apart from this, risk taking ability, access to credit and ability to relax capital constraints also affect adoption of conservation technology (Joshi et al., 2004).

The SWC programme failed in many situations to make any apparent impact on adoption of technologies by farmers. Farmers were interested in receiving free inputs and reverted to their former practices once the sponsored programme was withdrawn (Mishra and Tripathi, 2013). Dhyani et al., (2002) also found that farmers want government assistance in the form of technical, material and cash for implementation of conservation activities.

\section{Exogenous variables}

There are many variables within an agricultural system which influence farmers' decisions regarding adoption of SWC measures. They are known as exogenous variables. Without knowledge of practices associated with conservation technology via some formal and informal information, adoption is implausible.

Indeed, studies of innovation adoption and diffusion have long recognized information as a key variable, and its availability has been found to correlate with adoption (Harrera and Sain, 1999). Singh et al., (2011) found that formal source of knowledge had positive impact on adoption of Resource Conservation Technology (RCT), and they also indicated that informal source of knowledge disfavours adoption. The farmers rely more on formal source of information when it comes to adopting new technology.

Badal et al., (2006) and Mondal et al., (2013) 
found that institutional effectiveness and extension (contact with extension agencies and visit of extension workers) had significant and positive influence on participation in watershed development programmes. Benal et al., (2010) also found that information source utilization, extension participation, mass media exposure had significant and positive correlation with adoption of recommended dryland agricultural technology. Nirmala et al., (2003) also revealed that local institution is necessary for favour of people's participation, through activities which include local group discussion, and visit to communities where new policies/technologies had been successfully implemented.

Rao et al., (2004) found that the success of a watershed programme was significantly influenced by extent of augmentation of ground water and access to markets. Joshi et al., (2004) reported that change in market structure; input-output prices, subsidies, population growth and external aid are important variables that affect the sustainability of local resource use.

Table.1 Variables found to significantly affect farmers' adoption of soil and water conservation measures in at least one analysis

\begin{tabular}{|c|c|c|c|}
\hline $\begin{array}{l}\text { Farm household } \\
\text { characteristic }\end{array}$ & $\begin{array}{l}\text { Farm } \\
\text { biophysical } \\
\text { characteristics }\end{array}$ & $\begin{array}{l}\text { Farm financial } \\
\text { characteristics }\end{array}$ & $\begin{array}{l}\text { Exogenous } \\
\text { variables }\end{array}$ \\
\hline Age & Slope & Land tenure & Source of knowledge \\
\hline Caste & Land holding & Net returns & Extension \\
\hline Education & $\begin{array}{l}\text { Operational } \\
\text { land holding }\end{array}$ & Profit & $\begin{array}{l}\text { Extension } \\
\text { participation }\end{array}$ \\
\hline Family size & Soil erosion & Total annual income & $\begin{array}{l}\text { Economic } \\
\text { motivation }\end{array}$ \\
\hline Awareness & $\begin{array}{l}\text { Total cropped } \\
\text { area irrigated }\end{array}$ & Cash crop income & $\begin{array}{l}\text { Information source } \\
\text { utilization }\end{array}$ \\
\hline Income & & Share of livestock & \\
\hline Socio-economic status & & $\begin{array}{l}\text { Share of off-farm and } \\
\text { non-farm income }\end{array}$ & $\begin{array}{l}\text { Mass media } \\
\text { exposure }\end{array}$ \\
\hline $\begin{array}{l}\text { No. of farm family } \\
\text { workers }\end{array}$ & & Share of vegetable crops & Cosmopolitans \\
\hline Social participation & & $\begin{array}{l}\text { Share of cereals and } \\
\text { pulses }\end{array}$ & $\begin{array}{l}\text { Visit of extension } \\
\text { workers }\end{array}$ \\
\hline Poverty index & & Share of fruit crops & Local institution \\
\hline $\begin{array}{l}\text { Perception of effect of soil } \\
\text { and water degradation on } \\
\text { crop yield }\end{array}$ & & Horsepower of pump & Trainings imparted \\
\hline Innovativeness & & $\begin{array}{l}\text { Number of days spent } \\
\text { on off farm employment }\end{array}$ & \\
\hline Scientific orientation & & Credit worthiness & \\
\hline $\begin{array}{l}\text { Attitude towards modern } \\
\text { technology }\end{array}$ & & & \\
\hline
\end{tabular}


Conclusion of the study is as follows:

It is clear from the review that the adoption of SWC measures is influenced by a number of variables (farmers' age, education level, family size, perceptions on soil erosion, awareness about SWC measures and their long term profitability, social participation and socio-economic status, farm size, livestock size, off farm income and off farm employment, land tenure security, farm net return, source of knowledge, institutional effectiveness and extension services) and thereis disparity in the relative importance of the factors which determining the adoption decision of SWC measures of farmers under varying agro-ecological and socio-economic conditions. Thus, the variables are very context specific and it remains a challenge to formulate general policies and measures that encourage adoption of SWC measures. Indeed, there is a need for targeted policy approach for promoting these measures, whereby policy mechanisms such as grants or extension services are furnished to particulars of a locale or preferably to individual farmers.

The majority of SWC measures recommended only for conserving soil and water, whereas farmers have multifaceted objectives like direct and indirect benefits. Nevertheless, one common and important factor for adoption of any new intervention is the profitability for the farmer. If farmers have a prospect of gaining financial benefits (e.g. increase production, reduce labour input, higher offfarm income, etc.) they will be more motivated to adopt, maintain and replicate of interventions. The implementation of SWC measures should thus not be an activity on its own, but always be accompanied with measures and motivating activities that improve the future prospects of increasing income for the farmers. Also wherever, farmers are not aware about benefits of SWC measures or do not have the skills to implement it, they need education and technical assistance. It is also important to demonstrate the benefits of adoption of SWC measures or the losses associated with nonadoption of these measures.

\section{Acknowledgements}

The authors thank the Director of IISWC, Dehradun and CRIDA, Hyderabad for providing all the required facilities.

\section{References}

Anonymous. 2010. Degraded and Wastelands of India: Status and Spatial Distribution. Indian Council of Agricultural Research, New Delhi and National Academy of Agricultural Sciences, New Delhi (2010), 158p.

Anonymous. 2016. Agricultural Statistics at a Glance. New Delhi: Ministry of Agriculture and Farmers' Welfare.

Anonymous. 2018. Agricultural Statistics at a Glance. New Delhi: Ministry of Agriculture and Farmers' Welfare.

Badal, P.S. Kumar, P. and Bisaria, G. 2006. Dimensions and determinants of peoples' participation in watershed development programmes in Rajasthan. Agric. Econ. Res. Review, 19(1): 57-69.

Bagdi, G.L., Samra, J.S., and Kumar, V. 2001. Adoption of soil and water conservation technologies by the farmers of Sardar Sarovar Project Catchment in Gujarat State. Ind. J. Soil Cons., 29 (1): 65-68.

Barman, R.N. and Das, R. 2010. A study of socio-economic factors influencing adoption of farm level soil and water conservation practices in the ravine area of North bank plain zone of Assam. Ind. J. Agric. Econ., 65(3): 430-447.

Benal, D., Patel, M.M., Jain, M.P. and Singh, V.B. 2010. Adoption of dryland technology. Ind. J. Dryland Agric. Res. 
\& Dev., 25(1): 111-116.

Dhyani, B.L., Babu, R., Samra, J.S. and Kumar, N. 2002. Effect of integrated watershed management programme on farmer's attitude to land management. Ind. J. Dryland Agric. Res. \& Dev., 17(1): 14-19.

Feder, G., Just, R., Zilberman, D. 1985. Adoption of agricultural innovations in developing countries: a survey. Econ.Dev.\&Cul. Change, 33 (2): 255 298.

Gamit, M.K., Durgga, R.V., Bhabhor, I., Rathod, A. and Vyas H. 2015. Integrated Farming System for Ecological Sustainability and Livelihood Security. Trends in Biosciences. 8(14): 3509-3515.

Gould, B.W., Kangasniemi, W.E. and Klemme, R.M. 1989. Conservation tillage: the role of farm and operator characteristics and the perception of soil erosion. Land Econ., 65 (2): 167-182.

Harrera, A.P. and Sain, G. 1999. Adoption of maize conservation tillage in Azuero, Panama. Economics. Working Paper, 99-01.The International Maize and Wheat Improvement Center.

Joshi, P.K., Pangare, V., Shiferaw, B., Wani, S.P., Bouma, J. and Scott, C. 2004.Socioeconomic and policy research on watershed management in India: Synthesis of past experiences and needs for future research. Global Theme on Agro ecosystems, Report No. 7, ICRISAT, p88.

Kerr, M.J. and Sanghi, N.K.1992.Indigenous soil and water conservation in India's Semi-Arid Tropics. Sustainable Agriculture Programme Gatekeeper Series Paper no.34, London: IIET.

Kumar, S., Sharma, K.L., Kareemulla, K., Chary, G.R., Ramarao, C.A., Rao, S. and Venkateswarlu, B. 2011. Technoeconomic feasibility of conservation agriculture in rainfed regions of India.
Curr. Sci., 101(9 \&10): 1171-1181.

Mahboubi, M.R., Irvani, H. Rezvanfar, A. Kalantari, K. and Saravi, M.M. 2005. Factors affecting the adoption behaviour regarding soil conservation technologies in the ZarrinGol, Watershed in Golestanprovince. Iranian J. Natural Reso., 57 (4): 595-606.

Mishra, P.K. and Tripathi, K.P. 2013. Soil and water conservation research for land management in India. Ind. $J$. Dryland Agric. Res. \& Dev., 28(1): 0118.

Mondal, B., Singh, A. and Sekar, I. 2013. Dimensions and determinants of people's participation in watershed development programmes in Bundelkhand region of Madhya Pradesh: An econometric analysis. Ind. J. Soil Cons., 41(2): 177-184.

Nirmala, G., Sankar, G.R.M., Rao, N.B., Prasad, M.S. and Ramrao, C. A. 2003. Participatory watershed management programmes of Southern Telengana region of Andhra Pradesh, India. Ind. J. Dryland Agric. Res. \& Dev., 18(2): 118125.

Pande V.C., Kurothe, R.S., Singh, H.B. and Tiwari, S.P. 2011. Incentives for soil and water conservation on farm in ravines of Gujarat: Policy implications for future adoption. Agric. Econ. Res. Review, 24(2): 109-118.

Rao, N.B., Mishra, P.K. and Kumar, S.A. 2004. Adoption of soil and water conservation practices for Arable lands by the farmers of Rain fed Agro-eco system. Ind. J. Dryland Agric. Res. \& Dev., 19(1): 48-53.

Reddy, B.V.C., Hoag, D. and Shobha, B.S. 2004. Economic incentives for soil conservation in India. $13^{\text {th }}$ International Soil Conservation Organization Conference, Brisbane.

Regassa, E.N., Upadhyay, B. and Nagar, R.K. 2003. Adoption and impacts of micro 
irrigation technologies. Research Report 93, International Water Management Institute, pp. 9-19.

Roger, E.M. 2003. Diffusion of Innovations. 5th Edn. New York: Free Press

Shankar, K.R., Subrahmanyam, K.V., Reddy, B.M.K. and Sharma, K.D. 2007. Farmers' perceptions and adoption patterns of soil and water conservation measures: A case in Nalgonda district of Andhra Pradesh. Ind. J. Dryland Agric. Res. \& Dev., 22(2): 197-200.

Singh, N.P., Singh, R.P., Kumar, R., Vashist, A.K., Khan, F. and Varghese. N. 2011. Adoption of resource conservation technologies in indo-gangetic plains of India: scouting for profitability and efficiency. Agric. Econ. Res. Review, 24(2): 15-24.

Singh, R.K., Singh, B.P., Baboo, B. and Singh B. 2009. Impact of in situ moisture conservation practices on soil moisture and growth of ber and kusum for sustained lac production in Jharkhand. Ind. J. Soil Cons., 36(2), 105-108.

Singh, S.V. and Singh, D.P. 2004. Adoption behaviour of the farmers of chhajawa watershed towards soil conservation technology. Ind. J. Agric. Res., 38(4): 256-261.

Soule, M.J., Tegene, A. and Wiebe, K.D. 2000. Land tenure and adoption of conservation practices. American $J$. Agric. Econ., 82(4): 993-1005.

Stonehouse, P.D. 1991. The economics of tillage for large-scale mechanized farms. Soil and Tillage Res., 20 (2-4): 333-352.

Venkateswarlu, B. and Prasad, J.V.N.S. 2012. Carrying capacity of Indian agriculture: issues related to rainfed agriculture. Curr. Sci., 102(6): 882-888.

\section{How to cite this article:}

Dinesh Chand Meena, C.A. Rama Rao, B.L. Dhyani, Pradeep Dogra, S.K. Dubey and Mishra, P.K. 2020. Factors Influencing Adoption of Soil and Water Conservation Measures in India: Reviewing the Evidence. Int.J.Curr.Microbiol.App.Sci. 9(06): 712-720. doi: https://doi.org/10.20546/ijcmas.2020.906.091 